\title{
Gold-catalyzed reaction of oxabicyclic alkenes with electron-deficient terminal alkynes to produce acrylate derivatives
}

\author{
Yin-wei Sun ${ }^{1}$, Qin Xu ${ }^{* 1}$ and Min Shi ${ }^{* 1,2, \S}$
}

\author{
Full Research Paper \\ Address: \\ ${ }^{1}$ Key Laboratory for Advanced Materials and Institute of Fine \\ Chemicals, School of Chemistry \& Molecular Engineering, East China \\ University of Science and Technology, 130 MeiLong Road, Shanghai \\ 200237, People's Republic of China, and ${ }^{2}$ State Key Laboratory of \\ Organometallic Chemistry, Shanghai Institute of Organic Chemistry, \\ Chinese Academy of Sciences, 354 Fenglin Road, Shanghai 200032, \\ People's Republic of China \\ Email: \\ Qin Xu* - qinxu@ecust.edu.cn; Min Shi* - Mshi@mail.sioc.ac.cn \\ * Corresponding author \\ § Fax: 86-21-64166128 \\ Keywords: \\ gold catalysis; oxabicyclic alkenes; substituted acrylates
}

Open Access

eilstein J. Org. Chem. 2013, 9, 1969-1976.

doi:10.3762/bjoc. 9.233

Received: 12 July 2013

Accepted: 10 September 2013

Published: 01 October 2013

This article is part of the Thematic Series "Gold catalysis for organic synthesis II".

Guest Editor: F. D. Toste

(c) 2013 Sun et al; licensee Beilstein-Institut.

License and terms: see end of document.

\begin{abstract}
Oxabicyclic alkenes can react with electron-deficient terminal alkynes in the presence of a gold catalyst under mild conditions, affording the corresponding addition products in moderate yields. When using alkynyl esters as substrates, the (Z)-acrylate derivatives are obtained. Using but-3-yn-2-one (ethynyl ketone) as a substrate, the corresponding addition product is obtained with $(E)$ configuration. The proposed mechanism of these reactions is also discussed.
\end{abstract}

\section{Introduction}

Oxabicyclic alkenes are common intermediates in organic synthesis since these compounds can be easily prepared and have a high reactivity for further transformations [1-8]. For example, they are often used to construct substituted tetrahydronaphthalene skeletons in the presence of metal catalysts such as $\mathrm{Pd}$ [9,10], Ir [11-15], $\mathrm{Rh}$ [16-21] and $\mathrm{Cu}$ [22]. However, their reactivity in the presence of gold catalysts has been rarely reported [23]. It is well known that gold catalysts have different catalytic abilities compared with other transition metals [24].
Moreover, gold-catalyzed chemical transformations have made significant progress during the last 5 years [25-56]. Many gold complexes have been proved to be efficient catalysts in $\mathrm{C}-\mathrm{C}$ [33-48] bond or $\mathrm{C}-\mathrm{X}(\mathrm{X}=$ heteroatom) [49-56] bond forming reactions. Our group has a long-standing interest in goldcatalyzed C-C [57-61] or C-X bond [62-67] formation reactions. So far, we have reported a variety of gold-catalyzed intramolecular rearrangements with highly strained small rings for $\mathrm{C}-\mathrm{C}$ or $\mathrm{C}-\mathrm{X}$ bond formations [57-59,62-68]. Based on these 
previous findings, we envisaged that oxabicyclic alkenes could also react with electron-deficient alkynes in the presence of gold catalysts to generate a new $\mathrm{C}-\mathrm{C}$ or $\mathrm{C}-\mathrm{O}$ bond thereby releasing the oxabicyclic alkenes of their ring strain. In this paper, we report the formation of $(Z)$-acrylate derivatives in the gold catalyzed intermolecular reaction of oxabicyclic alkenes with electron-deficient terminal alkynes under mild conditions [69-76] (Scheme 1).

\section{Results and Discussion}

To generate a new $\mathrm{C}-\mathrm{O}$ bond in the reaction of oxabicyclic alkene 1a with electron-deficient terminal alkyne 2a, we first used $\mathrm{PPh}_{3} \mathrm{AuCl}$ as a catalyst, $\mathrm{AgSbF}_{6}$ as an additive, and toluene as a solvent to examine the reaction outcome. Acrylate derivative 3a was formed with $(Z$ )-configuration in $11 \%$ yield (Table 1, entry 1). In this reaction, naphthalen-1-ol was also obtained with $44 \%$ yield as the major product. The usage of<smiles>[R]c1cc2c(cc1[R])C1C=CC2O1</smiles>

1, 1.0 equiv<smiles>[R]OC(=O)C#C[CH2-]</smiles>

2, 2.0 equiv<smiles>[R]O[R]</smiles>

3

Scheme 1: Gold-catalyzed reactions of oxabicyclic alkenes with electron-deficient terminal alkynes.

Table 1: Initial screening of the reaction conditions

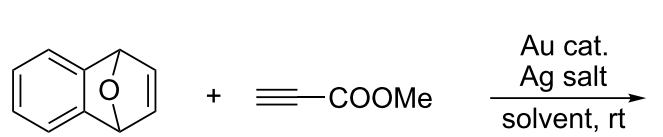

$1 \mathrm{a}, 1.0$ equiv 2a, 2.0 equiv<smiles>COC(C)=CCOc1cccc2ccccc12</smiles>

$3 a$

\begin{tabular}{|c|c|c|c|c|}
\hline Entry $^{a}$ & Au cat. & Ag salt & Solvent & Yield $^{b}(\%) 3 a$ \\
\hline $1^{c}$ & $\mathrm{Ph}_{3} \mathrm{PAuCl}$ & $\mathrm{AgSbF}_{6}$ & toluene & 11 \\
\hline 2 & IPrAuCl & $\mathrm{AgSbF}_{6}$ & toluene & 19 \\
\hline 3 & $\mathrm{dppb}(\mathrm{AuCl})_{2}$ & $\mathrm{AgSbF}_{6}$ & toluene & trace \\
\hline 4 & $\left(p-\mathrm{FC}_{6} \mathrm{H}_{4}\right)_{3} \mathrm{PAuCl}$ & $\mathrm{AgSbF}_{6}$ & toluene & 26 \\
\hline 5 & DPE-phos $(\mathrm{AuCl})_{2}$ & $\mathrm{AgSbF}_{6}$ & toluene & N.R. \\
\hline 6 & $\mathrm{Me}_{3} \mathrm{PAuCl}$ & $\mathrm{AgSbF}_{6}$ & toluene & N.R. \\
\hline 7 & $\mathrm{Cy}_{3} \mathrm{PAuCl}$ & $\mathrm{AgSbF}_{6}$ & toluene & 34 \\
\hline 8 & 6 & $\mathrm{AgSbF}_{6}$ & toluene & 40 \\
\hline 9 & 6 & - & toluene & N.R. \\
\hline $10^{c}$ & None & $\mathrm{AgSbF}_{6}$ & toluene & trace \\
\hline 11 & 6 & $\mathrm{AgNTf}_{2}$ & toluene & 32 \\
\hline 12 & 6 & AgOTs & toluene & N.R. \\
\hline 13 & 6 & $\mathrm{CF}_{3} \mathrm{COOAg}$ & toluene & N.R. \\
\hline 14 & 6 & AgOTf & toluene & 20 \\
\hline 15 & XPhosAuNTf 2 & - & toluene & 33 \\
\hline 16 & XPhosAu(MeCN)SbF 6 & - & toluene & 45 \\
\hline 17 & XPhosAu(MeCN)SbF 6 & - & $\mathrm{CH}_{3} \mathrm{CN}$ & trace \\
\hline 18 & XPhosAu(MeCN)SbF 6 & - & $\mathrm{CH}_{3} \mathrm{NO}_{2}$ & N.R. \\
\hline 19 & XPhosAu(MeCN)SbF 6 & - & $\mathrm{Et}_{2} \mathrm{O}$ & N.R. \\
\hline 20 & XPhosAu(MeCN)SbF 6 & - & THF & complex \\
\hline 21 & XPhosAu(MeCN)SbF 6 & - & $\mathrm{DCM}$ & 25 \\
\hline 22 & XPhosAu(MeCN)SbF 6 & - & DCE & 28 \\
\hline $23^{d}$ & XPhosAu(MeCN)SbF 6 & - & toluene & 10 \\
\hline
\end{tabular}

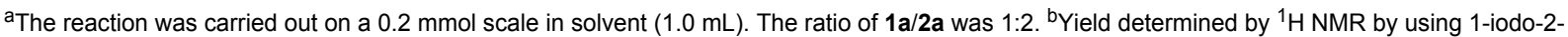
methoxybenzene (4) as an internal standard. CNaphthalen-1-ol (5) was the major product. d50 mg of $4 \AA$ MS was added to the reaction system. 
IPrAuCl, dppb(AuCl $)_{2},\left(p-\mathrm{FC}_{6} \mathrm{H}_{4}\right)_{3} \mathrm{PAuCl}, \mathrm{DPE}-\mathrm{phos}(\mathrm{AuCl})_{2}$, $\mathrm{Me}_{3} \mathrm{PAuCl}$ and $\mathrm{Cy}_{3} \mathrm{PAuCl}$ as gold catalysts did not significantly improve the yield of $\mathbf{3 a}$ (Table 1, entries 2-7). In these cases, the maximum yield of $\mathbf{3 a}$ was $34 \%$ when the gold complex $\mathrm{Cy}_{3} \mathrm{PAuCl}$ coordinated by an electron-rich phosphine ligand was used as a catalyst (Table 1, entry 7). In order to further improve the yield of 3a, we employed gold complex $\mathbf{6}$ (Figure 1) coordinated by a sterically bulky and electron-rich biaryl phosphine-type ligand as a catalyst, affording $\mathbf{3 a}$ in $40 \%$ yield (Table 1, entry 8). In the absence of $\mathrm{AgSbF}_{6}$, no reaction occurred (Table 1, entry 9). The usage of $\mathrm{AgSbF}_{6}$ as a catalyst produced naphthalen-1-ol (5) as the major product (Table 1, entry 10). Next, we further screened the reaction conditions with gold complex 6 as a catalyst. When using AgOTs or $\mathrm{CF}_{3} \mathrm{CO}_{2} \mathrm{Ag}$ as a silver additive, we did not obtain any of the desired products (Table 1, entries 12 and 13), whereas the usage of $\mathrm{AgNTf}_{2}$ as a silver additive afforded 3a in $32 \%$ yield (Table 1, entry 11). AgOTf was not an effective silver additive, giving $3 \mathbf{a}$ in $20 \%$ yield (Table 1, entry 14). Utilization of the already prepared electrophilic cationic phosphinogold(I) complexes XPhosAuNTf 2 and $\mathrm{XPhosAu} \mathrm{MeCN}) \mathrm{SbF}_{6}$ as gold catalysts slightly increased the yield of $\mathbf{3 a}$ to $33 \%$ and $45 \%$ yields, respectively (Table 1, entries 15 and 16). The examination of solvent effects revealed that toluene was the best solvent
(Table 1, entries 17-22). Adding $4 \AA$ MS into the reaction system, $3 \mathbf{a}$ was obtained in only $10 \%$ yield (Table 1 , entry 23 ).

Since the yield of $\mathbf{3 a}$ was still low, we next tried to improve the yield of 3a by deploying different ligands, Ag salts, solvents and temperature. The results are summarized in Table 2. At first, we examined many other gold(I) phosphane complexes with dialkylbiarylphosphane ligands (Figure 1) by using $\mathrm{AgSbF}_{6}$ as an additive and toluene as a solvent. No reaction occurred when gold(I) phosphane complexes 8-10 (Figure 1) were used as catalysts under identical conditions (Table 2, entries 2-4). Furthermore, the usage of gold(I) phosphane complexes 7, 11, 13 and $\mathbf{1 4}$ (Figure 1) as catalysts gave 3a in 10-29\% yields (Table 2, entries 1, 5, 7 and 8). Gold complex 12 (Figure 1) with an electron-rich biphenylphosphine ligand was identified as the best catalyst, giving 3a in 67\% yield (Table 2, entry 6). We attempted to further optimize the reaction conditions by using SPhosAuCl 12 as a catalyst and $\mathrm{AgNTf}_{2}$ or $\mathrm{AgSbF}_{6}$ as an additive and obtained $3 \mathrm{a}$ in $66 \%$ and $67 \%$ yields, respectively (Table 2, entries 6 and 9). However, the use of AgOTf or $\mathrm{AgBF}_{4}$ as an additive afforded $3 \mathbf{a}$ in $37 \%$ and $11 \%$ yields, respectively (Table 2, entries 10 and 11). Employment of the prepared electrophilic cationic phosphinogold(I) complex $\mathrm{SPhos} \mathrm{Au}(\mathrm{MeCN}) \mathrm{SbF}_{6}$ as a catalyst gave $\mathbf{3 a}$ in $78 \%$ NMR based<smiles>CC(C)c1cc(C(C)C)c(-c2ccccc2P)c(C(F)(Cl)Cl)c1</smiles>

6<smiles>Cc1cc(C(C)C)c(-c2c(C(C)C)cc(C(C)C)cc2C(C)C)c(C)c1C</smiles>

9<smiles>COc1cccc(OC)c1-c1ccccc1P(C)(F)(Cl)Cl</smiles>

12<smiles>CCCC[PH2+](c1ccccc1-c1c(C(C)C)cc(C(C)(C)C)cc1C(C)C)C(C)C</smiles><smiles>CCCCCCCCCCCCCCCCCC(Cl)c1ccccc1-c1ccccc1</smiles>

10<smiles>ClC(Cl)(Cl)c1ccccc1-c1ccccc1</smiles>

13<smiles>COc1ccc(OC)c(-c2c(C(F)(F)F)cc(C(F)(F)F)cc2C(F)(Cl)Cl)c1-c1c(C(C)C)cc(C(F)(F)F)cc1C(C)C</smiles><smiles>Cc1cc(-c2c(C(C)C)cc(C(C)C)c(C)c2C)c(PC(Cl)(Cl)Cl)c(C)c1C</smiles>

11<smiles>Cc1ccccc1-c1ccccc1PC(Cl)(Cl)Cl</smiles>

14

Figure 1: Gold complexes used in this reaction. 
Table 2: Further screening of the reaction conditions.

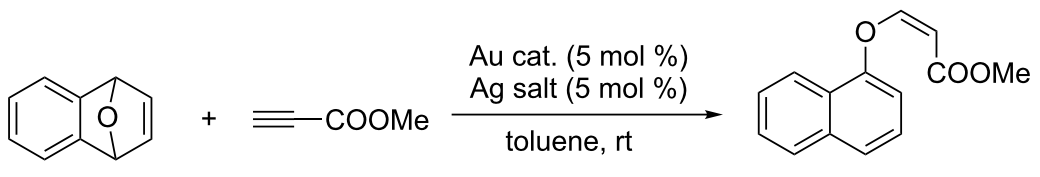

1 a

2a, 2.0 equiv

$3 \mathbf{a}$

\begin{tabular}{|c|c|c|c|c|c|}
\hline entry $^{a}$ & Au cat. & Ag salt & solvent & $T\left({ }^{\circ} \mathrm{C}\right)$ & Yield $^{b}(\%) 3 a$ \\
\hline $1^{\mathrm{c}}$ & 7 & $\mathrm{AgSbF}_{6}$ & toluene & $\mathrm{rt}$ & 11 \\
\hline 2 & 8 & $\mathrm{AgSbF}_{6}$ & toluene & $\mathrm{rt}$ & N.R. \\
\hline 3 & 9 & $\mathrm{AgSbF}_{6}$ & toluene & $\mathrm{rt}$ & trace \\
\hline 4 & 10 & $\mathrm{AgSbF}_{6}$ & toluene & $\mathrm{rt}$ & N.R. \\
\hline 5 & 11 & $\mathrm{AgSbF}_{6}$ & toluene & $\mathrm{rt}$ & 10 \\
\hline 6 & 12 & $\mathrm{AgSbF}_{6}$ & toluene & $\mathrm{rt}$ & 67 \\
\hline 7 & 13 & $\mathrm{AgSbF}_{6}$ & toluene & $\mathrm{rt}$ & 20 \\
\hline 8 & 14 & $\mathrm{AgSbF}_{6}$ & toluene & $\mathrm{rt}$ & 29 \\
\hline 9 & 12 & $\mathrm{AgNTf}_{2}$ & toluene & $\mathrm{rt}$ & $66(59)^{c}$ \\
\hline 10 & 12 & AgOTf & toluene & $\mathrm{rt}$ & 37 \\
\hline 11 & 12 & $\mathrm{AgBF}_{4}$ & toluene & $\mathrm{rt}$ & 11 \\
\hline 12 & SPhosAu(MeCN)SbF 6 & - & toluene & $\mathrm{rt}$ & $78(67)^{\mathrm{C}}$ \\
\hline 13 & SPhosAuNTf 2 & - & toluene & $\mathrm{rt}$ & 53 \\
\hline 14 & SPhosAu(MeCN)SbF 6 & - & $\mathrm{DCM}$ & $\mathrm{rt}$ & 49 \\
\hline 15 & SPhosAu(MeCN)SbF 6 & - & DCE & $\mathrm{rt}$ & 55 \\
\hline 16 & SPhosAu(MeCN)SbF 6 & - & $\mathrm{CHCl}_{3}$ & $\mathrm{rt}$ & 45 \\
\hline $17^{d}$ & SPhosAu(MeCN)SbF 6 & - & toluene & 0 & 50 \\
\hline 18 & SPhosAu(MeCN)SbF 6 & - & toluene & 40 & 45 \\
\hline 19 & SPhosAu(MeCN)SbF 6 & - & toluene & 10 & 59 \\
\hline 20 & SPhosAu(MeCN)SbF 6 & - & toluene & 30 & 70 \\
\hline
\end{tabular}

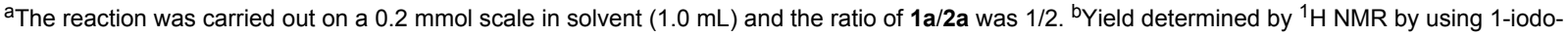
2-methoxybenzene $\mathbf{4}$ as an internal standard. CIsolated yield in parentheses.

yield and $67 \%$ isolated yield (Table 2 , entry 12 ). The phosphinogold(I) complex SPhosAuNTf 2 produced 3a in 53\% yield under the standard conditions (Table 2, entry 13). The examination of solvent effects disclosed that toluene was the best solvent (Table 2, entries 14-16). Either increasing or decreasing the reaction temperature did not further improve the reaction outcome (Table 2, entries 17-20). Careful screening of the reaction conditions led to the conclusion that the reaction should be carried out in toluene at room temperature with $\mathrm{SPhosAu}(\mathrm{MeCN}) \mathrm{SbF}_{6}$ as the catalyst (Table 2, entry 12).

Having identified the optimal conditions, we next examined the substrate scope of this reaction. We found that only the usage of ethynylbenzene and dimethyl but-2-ynedioate as substrates did not afford any of the desired products (Table 3, entries 6 and 9). In all other cases, the reactions proceeded smoothly to give the desired products in moderate to good yields (Table 2, entries $1-5,7$ and 8$)$. The introduction of electron-donating substituents on the benzene ring impaired the reaction outcome (Table 3, entries 1 and 7). Increasing the steric hindrance of the ester group improved the yields of $\mathbf{3}$ (Table 3, entries 4 and 5). The usage of but-3-yne-2-one (terminal alkyne ketone) $2 \mathbf{i}$ as a substrate gave the corresponding $\mathbf{3 i}$ with $(E)$-configuration in $48 \%$ yield (Scheme 2 ).

Since naphthalene-1-ol (5) was obtained in this reaction, we used naphthalene-1-ol (5) as a substrate and carried out the reaction under the optimal conditions to clarify whether the reaction proceeded through naphthalene-1-ol. The formation of 3a could not be observed, suggesting that naphthalene-1-ol is not the intermediate in this reaction (Scheme 3).

Based on the previously established mechanistic model [23,77], we propose the following pathway for the formation of acrylate derivatives 3a and 3i (Scheme 4). In the presence of cationic phosphinogold(I) complex, a cationic intermediate $\mathbf{A}$ is formed by a regioselective opening of the oxygen bridge in substrate 1a. Intermediate $\mathbf{A}$ releases a proton to afford intermediate $\mathbf{B}$. Intermediate $\mathbf{B}$ attacks methyl propiolate, which is activated by the gold catalyst, to generate gold vinyl complex $\mathbf{C}$. In inter- 


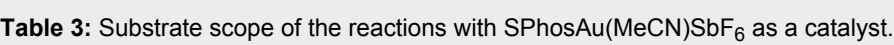

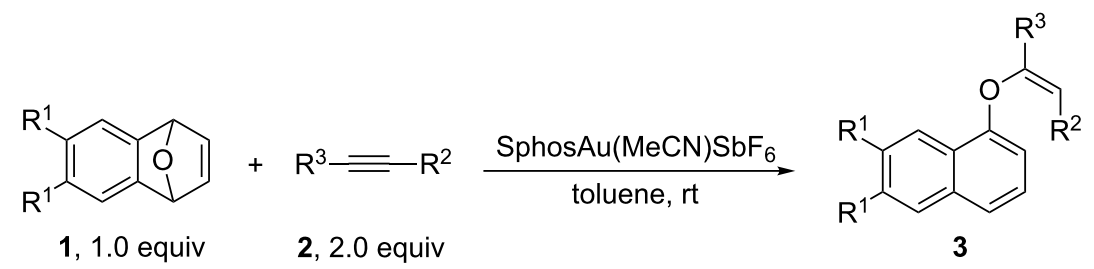

\begin{tabular}{cccc}
\hline entry & $\mathrm{R}^{1}$ & $\mathrm{R}^{2}, \mathrm{R}^{3}$ & Yield $^{\mathrm{b}}(\%) \mathbf{3}$ \\
\hline 1 & $\mathrm{Me}$ & COOMe, $\mathrm{H}$ & $\mathbf{3 b}, 42$ \\
2 & $\mathrm{~F}$ & COOMe, $\mathrm{H}$ & $\mathbf{3 c}, 66$ \\
3 & $\mathrm{Br}$ & COOMe, $\mathrm{H}$ & $\mathbf{3 d}, 76$ \\
4 & $\mathrm{H}$ & COOEt, $\mathrm{H}$ & $\mathbf{3 e}, 54$ \\
5 & $\mathrm{H}$ & COOt-Bu, $\mathrm{H}$ & $\mathbf{3 f}, 84$ \\
6 & $\mathrm{H}$ & $\mathrm{Ph}, \mathrm{H}$ & trace \\
7 & $\mathrm{Me}$ & COOt-Bu, $\mathrm{H}$ & $\mathbf{3 g}, 58$ \\
8 & $\mathrm{Br}$ & COOt-Bu, H & $\mathbf{3 h}, 72$ \\
9 & $\mathrm{H}$ & COOMe, COOMe & N.R. \\
\hline
\end{tabular}

aThe reaction was carried out on a $0.2 \mathrm{mmol}$ scale in solvent $(1.0 \mathrm{~mL})$. The ratio of $1 / 2$ was $1 / 2$. blsolated yield.<smiles>C1=CC2OC1c1ccccc12</smiles>

1a, 1.0 equiv

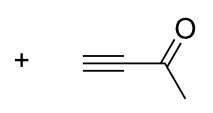

$\mathbf{2 i}, 2.0$ equiv
SPhosAu(MeCN)SbF toluene, rt<smiles>CC(=O)/C=C/Oc1cccc2ccccc12</smiles>

$3 i, 48 \%$ yield

Scheme 2: The reaction with terminal alkyne $\mathbf{2} \mathbf{i}$ as a substrate.<smiles>Oc1cccc2ccccc12</smiles>

$5,1.0$ equiv

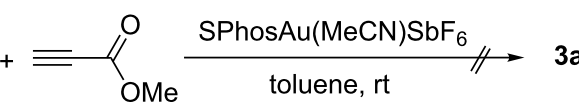

2a, 2.0 equiv mediate $\mathbf{C}$, the ester group and the naphthalene ring are on the same side, yielding the final product 3a with $(Z)$-configuration via protodeauration. The alkyne ketone $\mathbf{3 i}$ is more electron-deficient and more reactive than methyl propiolate and it is more difficult to coordinate by the gold complex. Therefore, with alkyne ketone $\mathbf{2} \mathbf{i}$ as a substrate, intermediate $\mathbf{B}$ attacks non-coordinated alkyne ketone $\mathbf{2} \mathbf{i}$ in a cis-addition manner to generate gold vinyl complex D. In intermediate $\mathbf{D}$, the carbonyl group and the naphthalene ring are on opposite sides, affording product $3 \mathbf{i}$ with $(E)$-configuration by protodeauration.

\section{Conclusion}

In summary, we have developed a novel method to synthesize acrylate derivatives from oxabicyclic alkenes and electron-deficient terminal alkynes in toluene in moderate to good yields in the presence of the gold catalyst $\mathrm{SPhos} \mathrm{Au}(\mathrm{MeCN}) \mathrm{SbF}_{6}$ under mild conditions. Efforts are in progress to elucidate the mechanistic details of this reaction and to disclose its scope and limitations.

\section{Experimental \\ General remarks}

Dichloromethane was freshly distilled from calcium hydride; THF and toluene were distilled from sodium under an argon atmosphere. ${ }^{1} \mathrm{H}$ NMR, ${ }^{13} \mathrm{C}$ NMR and ${ }^{19} \mathrm{~F}$ NMR spectra were recorded on a Bruker AM-400 spectrometer. Infrared spectra were recorded on a Perkin-Elmer PE-983 spectrometer with absorption in $\mathrm{cm}^{-1}$. Flash column chromatography was performed by using 300-400 mesh silica gel. For thin-layer 


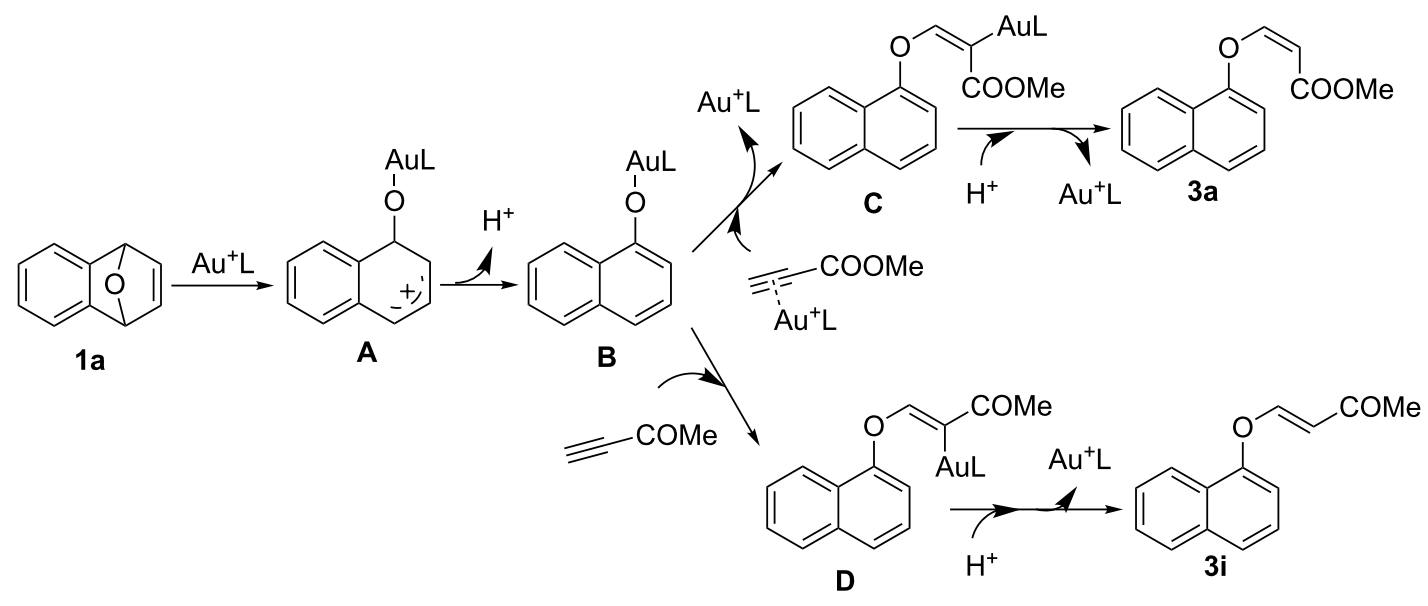

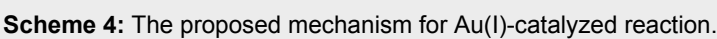

chromatography (TLC), silica gel plates (Huanghai GF254) were used. Mass spectra were recorded by ESI, and HRMS were measured on a HP-5989 instrument.

\section{General procedure for the reaction catalyzed by $\mathrm{Au}(\mathrm{I})$ catalysts}

Into an oven-dried reaction flask under $\mathrm{Ar}$ gas protection was added oxabicyclic alkene $(0.2 \mathrm{mmol}), \mathrm{Au}$ catalyst $(0.001 \mathrm{mmol})$, methyl propiolate $(0.4 \mathrm{mmol})$ and toluene $(1.0 \mathrm{~mL})$. The reaction mixture was stirred at room temperature normally overnight. After complete consumption of the starting materials, monitored by TLC, the solvent was removed under reduced pressure and the residue was purified by flash column chromatography.

\section{Supporting Information}

\section{Supporting Information File 1}

Experimental procedures and characterization data of compounds.

[http://www.beilstein-journals.org/bjoc/content/ supplementary/1860-5397-9-233-S1.pdf]

\section{Acknowledgements}

Financial support from the Shanghai Municipal Committee of Science and Technology (08dj1400100-2), the Fundamental Research Funds for the Central Universities, the National Basic Research Program of China (973)-2010CB833302, the Fundamental Research Funds for the Central Universities, and the National Natural Science Foundation of China (21072206, 20902019, 20472096, 20872162, 20672127, 20732008, 20821002, and 20702013) are gratefully acknowledged.

\section{References}

1. Tsui, G. C.; Tsoung, J.; Dougan, P.; Lautens, M. Org. Lett. 2012, 14, 5542-5545. doi:10.1021/ol302646a

2. Mannathan, S.; Cheng, C.-H. Chem. Commun. 2013, 49, 1557-1559. doi:10.1039/C2CC38001C

3. Sawano, T.; Ou, K.; Nishimura, T.; Hayashi, T. Chem. Commun. 2012, 48, 6106-6108. doi:10.1039/C2CC31880F

4. Jack, K.; Fatila, E.; Hillis, C.; Tam, W. Synth. Commun. 2013, 43, 1181-1187. doi:10.1080/00397911.2011.626140

5. Endo, K.; Tanaka, K.; Ogawa, M.; Shibata, T. Org. Lett. 2011, 13, 868-871. doi:10.1021/ol102928q

6. Madan, S.; Cheng, C.-H. J. Org. Chem. 2006, 71, 8312-8315. doi:10.1021/jo061477h

7. Lautens, M.; Rovis, T. J. Org. Chem. 1997, 62, 5246-5247. doi:10.1021/jo971115x

8. Barluenga, J.; Rodriguez, F.; Alvarez-Rodrigo, L.; Zapico, J. M.; Fañanás, F. J. Chem.-Eur. J. 2004, 10, 109-116. doi:10.1002/chem.200305374

9. Ge, G.-C.; Mo, D.-L.; Ding, C.-H.; Dai, L.-X.; Hou, X.-L. Org. Lett. 2012, 14, 5756-5759. doi:10.1021/ol302586m

10. Huang, X.-J.; Mo, D.-L.; Ding, C.-H.; Hou, X.-L. Synlett 2011, 943-946. doi:10.1055/s-0030-1259716

11. Hu, J.; Yang, Q.; Yu, L.; Xu, J.; Liu, S.; Huang, C.; Wang, L.; Zhou, Y.; Fan, B. Org. Biomol. Chem. 2013, 11, 2294-2301. doi:10.1039/C3OB27382B

12. Hu, J.; Yang, Q.; Xu, J.; Huang, C.; Fan, B.; Wang, J.; Lin, C.; Bian, Z.; Chan, A. S. C. Org. Biomol. Chem. 2013, 11, 814-820. doi:10.1039/C2OB26775F

13. Cheng, H.; Yang, D. J. Org. Chem. 2012, 77, 9756-9765. doi:10.1021/jo3018507

14. Yang, D.; Long, Y.; Zhang, J.; Zeng, H.; Wang, S.; Li, C. Organometallics 2010, 29, 3477-3480. doi:10.1021/om100384q

15. Fan, B.-M.; Li, X.-J.; Peng, F.-Z.; Zhang, H.-B.; Chan, A. S. C.; Shao, Z.-H. Org. Lett. 2010, 12, 304-306. doi:10.1021/ol902574c

16. Tsui, G. C.; Dougan, P.; Lautens, M. Org. Lett. 2013, 15, 2652-2655. doi: $10.1021 / 014009393$

17. Tsui, G. C.; Ninnemann, N. M.; Hosotani, A.; Lautens, M. Org. Lett. 2013, 15, 1064-1067. doi:10.1021/ol4000668 
18. Zhu, J.; Tsui, G. C.; Lautens, M. Angew. Chem., Int. Ed. 2012, 51, 12353-12356. doi:10.1002/anie.201207356

19. Tsui, G. C.; Lautens, M. Angew. Chem., Int. Ed. 2012, 51, 5400-5404. doi:10.1002/anie.201200390

20. Preetz, A.; Kohrt, C.; Drexler, H.-J.; Torrens, A.; Buschmann, H.; Lopez, M. G.; Heller, D. Adv. Synth. Catal. 2010, 352, 2073-2080. doi:10.1002/adsc.201000236

21. Long, Y.; Zhao, S.; Zeng, H.; Yang, D. Catal. Lett. 2010, 138, 124-133. doi:10.1007/s10562-010-0383-3

22. Bos, P. H.; Rudolph, A.; Pérez, M.; Fañanás-Mastral, M.; Harutyunyan, S. R.; Feringa, B. L. Chem. Commun. 2012, 48, 1748-1750. doi:10.1039/C2CC16855C

23. Sawama, Y.; Kawamoto, K.; Satake, H.; Krause, N.; Kita, Y. Synlett 2010, 2151-2155. doi:10.1055/s-0030-1258528

24. Brazeau, J.-F.; Zhang, S.; Colomer, I.; Corkey, B. K.; Toste, F. D. J. Am. Chem. Soc. 2012, 134, 2742-2749. doi:10.1021/ja210388g

25. Fortman, G. C.; Nolan, S. P. Chem. Soc. Rev. 2011, 40, 5151-5169. doi:10.1039/C1CS15088J

26. Sethofer, S. G.; Mayer, T.; Toste, F. D. J. Am. Chem. Soc. 2010, 132, 8276-8277. doi:10.1021/ja103544p

27. Rudolph, M. In Modern Gold Catalyzed Synthesis; Hashmi, A. S. K.; Toste, F. D., Eds.; Wiley: Weinheim, Germany, 2012; pp 331-362.

28. Hubbert, C.; Hashmi, A. S. K. In Modern Gold Catalyzed Synthesis, Hashmi, A. S. K.; Toste, F. D., Eds.; Wiley: Weinheim, Germany, 2012; pp 237-262.

29. Shapiro, N. D.; Toste, F. D. Synlett 2010, 675-691. doi:10.1055/s-0029-1219369

30. Liu, W.; Gust, R. Chem. Soc. Rev. 2013, 42, 755-773. doi:10.1039/C2CS35314H

31. Chi, Y.; Chou, P.-T. Chem. Soc. Rev. 2010, 39, 638-655. doi:10.1039/B916237B

32. Cheon, C. H.; Kanno, O.; Toste, F. D. J. Am. Chem. Soc. 2011, 133, 13248-13251. doi:10.1021/ja204331w

33. Benitez, D.; Tkatchouk, E.; Gonzalez, A. Z.; Goddard, W. A., III; Toste, F. D. Org. Lett. 2009, 11, 4798-4801. doi:10.1021/ol9018002

34. Mauleón, P.; Zeldin, R. M.; González, A. Z.; Toste, F. D. J. Am. Chem. Soc. 2009, 131, 6348-6349. doi:10.1021/ja901649s

35. Hashmi, A. S. K.; Hengst, T.; Lothschütz, C.; Rominger, F. Adv. Synth. Catal. 2010, 352, 1315-1337. doi:10.1002/adsc.201000126

36. Kusama, H.; Karibe, Y.; Onizawa, Y.; Iwasawa, N. Angew. Chem., Int. Ed. 2010, 49, 4269-4272. doi:10.1002/anie.201001061

37. Jurberg, I. D.; Odabachian, Y.; Gagosz, F. J. Am. Chem. Soc. 2010, 132, 3543-3552. doi:10.1021/ja9100134

38. Bolte, B.; Gagosz, F. J. Am. Chem. Soc. 2011, 133, 7696-7699. doi:10.1021/ja202336p

39. Ye, L.; Wang, Y.; Aue, D. H.; Zhang, L. J. Am. Chem. Soc. 2012, 134, 31-34. doi:10.1021/ja2091992

40. Hashmi, A. S. K.; Braun, I.; Nösel, P.; Schädlich, J.; Wieteck, M.; Rudolph, M.; Rominger, F. Angew. Chem., Int. Ed. 2012, 51, 4456-4460. doi:10.1002/anie.201109183

41. Barluenga, J.; Sigüeiro, R.; Vicente, R.; Ballesteros, A.; Tomás, M.; Rodríguez, M. A. Angew. Chem., Int. Ed. 2012, 51, 10377-10381. doi:10.1002/anie.201205051

42. Mukherjee, P.; Widenhoefer, R. A. Chem.-Eur. J. 2013, 19, 3437-3444. doi:10.1002/chem.201203987

43. Alcarazo, M.; Stork, T.; Anoop, A.; Thiel, W.; Fürstner, A. Angew. Chem., Int. Ed. 2010, 49, 2542-2546. doi:10.1002/anie.200907194
44. Francos, J.; Grande-Carmona, F.; Faustino, H.; Iglesias-Sigüenza, J.; Díez, E.; Alonso, I.; Fernández, R.; Lassaletta, J. M.; López, F.; Mascareñas, J. L. J. Am. Chem. Soc. 2012, 134, 14322-14325. doi:10.1021/ja3065446

45. Yang, J.; Zhang, R.; Wang, W.; Zhang, Z.; Shi, M. Tetrahedron: Asymmetry 2011, 22, 2029-2038. doi:10.1016/j.tetasy.2011.12.004

46. Wang, W.; Yang, J.; Wang, F.; Shi, M. Organometallics 2011, 30 , 3859-3869. doi:10.1021/om2004404

47. Liu, L.; Wang, F.; Wang, W.; Zhao, M.; Shi, M. Beilstein J. Org. Chem. 2011, 7, 555-564. doi:10.3762/bjoc.7.64

48. Wang, F.; Li, S.; Qu, M.; Zhao, M.-X.; Liu, L.-J.; Shi, M. Beilstein J. Org. Chem. 2012, 8, 726-731. doi:10.3762/bjoc.8.81

49. Melhado, A. D.; Brenzovich, W. E., Jr.; Lackner, A. D.; Toste, F. D. J. Am. Chem. Soc. 2010, 132, 8885-8887. doi:10.1021/ja1034123

50. Shapiro, N. D.; Shi, Y.; Toste, F. D. J. Am. Chem. Soc. 2009, 131, 11654-11655. doi:10.1021/ja903863b

51. Tkatchouk, E.; Mankad, N. P.; Benitez, D.; Goddard, W. A., III; Toste, F. D. J. Am. Chem. Soc. 2011, 133, 14293-14300. doi:10.1021/ja2012627

52. Teng, T.-M.; Liu, R.-S. J. Am. Chem. Soc. 2010, 132, 9298-9300. doi:10.1021/ja1043837

53. Mukherjee, A.; Dateer, R. B.; Chaudhuri, R.; Bhunia, S.; Karad, S. N.; Liu, R.-S. J. Am. Chem. Soc. 2011, 133, 15372-15375. doi:10.1021/ja208150d

54. Wang, Y.-M.; Kuzniewski, C. N.; Rauniyar, V.; Hoong, C.; Toste, F. D. J. Am. Chem. Soc. 2011, 133, 12972-12975. doi:10.1021/ja205068j

55. Handa, S.; Slaughter, L. M. Angew. Chem., Int. Ed. 2012, 51 , 2912-2915. doi:10.1002/anie.201107789

56. Pérez-Galán, P.; Delpont, N.; Herrero-Gómez, E.; Maseras, F.; Echavarren, A. M. Chem.-Eur. J. 2010, 16, 5324-5332. doi:10.1002/chem.200903507

57. Zhu, Z.-B.; Shi, M. Chem.-Eur. J. 2008, 14, 10219-10222. doi:10.1002/chem.200801370

58. Lu, B.-L.; Wei, Y.; Shi, M. Chem.-Eur. J. 2010, 16, 10975-10979. doi:10.1002/chem.201001433

59. Jiang, M.; Liu, L.-P.; Shi, M.; Li, Y. Org. Lett. 2010, 12, 116-119. doi:10.1021/ol902593f

60. Zhang, D.-H.; Yao, L.-F.; Wei, Y.; Shi, M. Angew. Chem., Int. Ed. 2011, 50, 2583-2587. doi:10.1002/anie.201006969

61. Huang, L.; Yang, H.-B.; Zhang, D.-H.; Zhang, Z.; Tang, X.-Y.; Xu, Q.; Shi, M. Angew. Chem., Int. Ed. 2013, 52, 6767-6771. doi:10.1002/anie.201302632

62. Shi, M.; Liu, L.-P.; Tang, J. Org. Lett. 2006, 8, 4043-4046. doi:10.1021/ol0614830

63. Dai, L.-Z.; Qi, M.-J.; Shi, Y.-L.; Liu, X.-G.; Shi, M. Org. Lett. 2007, 9, 3191-3194. doi:10.1021/ol0713640

64. Tian, G.-Q.; Shi, M. Org. Lett. 2007, 9, 4917-4920. doi:10.1021/ol702341a

65. Dai, L.-Z.; Shi, M. Chem.-Eur. J. 2008, 14, 7011-7018. doi:10.1002/chem.200701954

66. Zhang, Z.; Shi, M. Chem.-Eur. J. 2010, 16, 7725-7729. doi:10.1002/chem.201000628

67. Lu, B.-L.; Shi, M. Chem.-Eur. J. 2011, 17, 9070-9075. doi:10.1002/chem.201100862

68. Lu, B.-L.; Dai, L.; Shi, M. Chem. Soc. Rev. 2012, 41, 3318-3339. doi:10.1039/C2CS15295A

69. Nasiri, F.; Malakutikhah, D. Monatsh. Chem. 2011, 142, 807-812. doi:10.1007/s00706-011-0514-6 
70. Kabir, M. S.; Namjoshi, O. A.; Verma, R.; Lorenz, M.;

Phani Babu Tiruveedhula, V. V. N.; Monte, A.; Bertz, S. H.;

Schwabacher, A. W.; Cook, J. M. J. Org. Chem. 2012, 77, 300-310. doi:10.1021/jo201948e

71. Tellam, J. P.; Kociok-Köhn, G.; Carbery, D. R. Org. Lett. 2008, 10, 5199-5202. doi:10.1021/ol802169j

72. Fan, M.-J.; Li, G.-Q.; Li, L.-H.; Yang, S.-D.; Liang, Y.-M. Synthesis 2006, 2286-2292. doi:10.1055/s-2006-942437

73. Mohrig, J. R.; Rosenberg, R. E.; Apostol, J. W.; Bastienaansen, M.; Evans, J. W.; Franklin, S. J.; Frisbie, C. D.; Fu, S. S.; Hamm, M. L.; Hirose, C. B.; Hunstad, D. A.; James, T. L.; King, R. W.; Larson, C. J.; Latham, H. A.; Owen, D. A.; Stein, K. A.; Warnet, R. J. Am. Chem. Soc. 1997, 119, 479-486. doi:10.1021/ja962631s

74. Yavari, I.; Souri, S.; Sirouspour, M.; Djahaniani, H.; Nasiri, F. Synthesis 2005, 1761-1764. doi:10.1055/s-2005-865359

75. Sarrafi, Y.; Sadatshahabi, M.; Alimohammadi, K.; Tajbakhsh, M. Green Chem. 2011, 13, 2851-2858. doi:10.1039/C1GC15625J

76. Zhou, W.; Zhang, Y.; Li, P.; Wang, L. Org. Biomol. Chem. 2012, 10, 7184-7196. doi:10.1039/C2OB25969A

77. Lautens, M.; Fagnou, K. Proc. Natl. Acad. Sci. U. S. A. 2004, 101, 5455-5460. doi:10.1073/pnas.0307271101

\section{License and Terms}

This is an Open Access article under the terms of the Creative Commons Attribution License

(http://creativecommons.org/licenses/by/2.0), which permits unrestricted use, distribution, and reproduction in any medium, provided the original work is properly cited.

The license is subject to the Beilstein Journal of Organic Chemistry terms and conditions:

(http://www.beilstein-journals.org/bjoc)

The definitive version of this article is the electronic one which can be found at: doi:10.3762/bjoc. 9.233 